\title{
Effect of phospholipase treatment on insulin receptor signal transduction
}

\author{
G.Zoppini and C.R.Kahn
}

Research Division, Joslin Diabetes Center, Departments of Medicine, Brigham and Women's Hospital, and Harvard Medical School, Boston, Massachusettes, USA

\begin{abstract}
Summary. To study the role of membrane lipids in signal transduction by the insulin receptor, we have studied the effect of phospholipase $\mathrm{C}$ (Clostridium perfringens) and a phosphatidylinositol-specific phospholipase (Staphylococcus aureus) on insulin binding, a function of the $\alpha$-subunit, and tyrosine kinase activity, a function of the $\beta$-subunit in IM-9 lymphocytes and NIH 3 T3 fibroblasts transfected with the human insulin receptor. Treatment of the cells with phospholipase $\mathrm{C}$ at concentrations up to $3.4 \mathrm{U} / \mathrm{ml}$ did not affect specific insulin binding, but reduced insulin-stimulated receptor phosphorylation by $50 \%$. This effect of phospholipase $\mathrm{C}$ was observed within $10 \mathrm{~min}$ of treatment and occurred with no change in the basal level of phosphorylation. Pre-treatment of cells with insulin for 5 min prior to enzyme addition prevented any change in kinase activity. Insulinstimulated phosphorylation of pp 185, the presumed endogenous substrate for the insulin receptor kinase, was also reduced following phospholipase $\mathrm{C}$ treatment, with an almost complete loss of insulin stimulation after exposure of
\end{abstract}

cells to enzyme at concentrations as low as $0.6 \mathrm{U} / \mathrm{ml}$. In contrast to these effects of phospholipase $\mathrm{C}$ on intact cells, receptor autophosphorylation was not affected in insulin receptors purified on wheat germ agglutinin-agarose from phospholipase $\mathrm{C}$ treated cells. Likewise, the phospholipase $\mathrm{C}$ effect was reduced by the addition of phosphatidylcholine, but not by the addition of the protease inhibitors, aprotinin and phenylmethylsulfonyl fluoride, to the incubation indicating its dependence on phospholipid hydrolysis. Treatment of cells with the phosphatidylinositol-specific phospholipase $\mathrm{C}$ did not affect any of the parameters studied. These data suggest that the phospholipid environment in the plasma membrane is an important modulator of transmembrane signalling within the insulin receptor heterotetramer and at the level of substrate phosphorylation.

Key words: Membrane lipids, insulin receptors, insulin action, tyrosine phosphorylation, pp 185.
Lipids play an important role in the structure and function of plasma membrane [1]. Membrane function is influenced by lipid composition, fluidity of the lipids in the membrane, and lipid-protein interactions [2,3]. Cell membrane fluidity is known to exert marked effects on the functional properties of many membrane proteins, including the insulin receptor [4-10]. The insulin receptor is an intrinsic membrane glycoprotein composed of two $\alpha$-subunits $\left(\mathrm{M}_{\mathrm{r}}=135,000\right)$ and two $\beta$-subunits $\left(\mathrm{M}_{\mathrm{r}}=95,000\right)$ joined by disulphide bonds to produce a tetrameric structure [11-14]. Insulin binding to the $\alpha$-subunit activates the tyrosine kinase in the $\beta$-subunit resulting in autophosphorylation of the $\beta$-subunit and stimulation of the phosphotransferase activity of the receptor toward tyrosine residues of other proteins [15-17]. Insulin receptor autophosphorylation appears to be a requisite step for the transmission of the insulin signal to metabolic pathways within the cell [18-20], however, the mechanism of the transduction of the signal from $\alpha$-subunit to $\beta$-subunits remains unknown.

Several types of studies have suggested a potential role for membrane lipids in insulin receptor signal transduction $[21,22]$. Although the $\beta$-subunit of the insulin receptor is a transmembrane protein, evidence has been presented to suggest that both subunits of the receptor are myristoylated, providing a possible interaction of the receptor with membrane lipids $[23,24]$. Increasing concentrations of saturated fatty acids in membranes of a variety of cells results in decreased insulin binding via changes in receptor affinity or number [7-10]. Treatment of isolated adipocytes with phospholipase $\mathrm{C}$ has also been shown to abolish insulin-stimulated glucose oxidation and anti-lipolysis, although the exact site of action of the enzyme in this context is unknown [25]. Interestingly, insulin treatment of cells appears to result in activation of one or more phospholipases, including a spe- 
cific phospholipase $\mathrm{C}$ which may generate an inositol glycan derivative capable of mimicking several of the actions of insulin [26-28].

In the present study, we have examined the effects of two different phospholipases on insulin action in NIH 3T3 HIR 3.5 fibroblasts and IM-9 lymphocytes. One is a phospholipase $\mathrm{C}$ with a broad specificity isolated from Clostridium perfringens; it's major activity is as a phosphatidylcholine phosphohydrolase $[29,30]$. The other is a phospholipase C from Staphylococcus aureus which is specific for glycosyl-phosphatidylinositol-anchored proteins [31]. We find that treatment of cells with the former, but not the latter, alters signal transduction at the level of tyrosine phosphorylation of the receptor and its primary substrate pp185 (the 185 kilodalton substrate of the insulin receptor kinase).

\section{Materials and methods}

\section{Materials}

$\mathrm{Na}^{125} \mathrm{I}-\left[\mathrm{Tyr}^{\mathrm{Al4}}\right]$ monoiodoinsulin $(2000 \mathrm{Ci} / \mathrm{mmol})$ was purchased from Amersham (Boston, Mass., USA); ${ }^{32} \mathrm{P}$-orthophosphate and $\gamma^{32}$ P[ATP] $(3000 \mathrm{Ci} / \mathrm{mmol}$ ) were purchased from New England Nuclear (Boston, Mass., USA); Clostridium perfringens phospholipase C (Type XIV) was obtained from Sigma Chemical Company (St.Louis, Mo., USA); phosphatidylinositol-specific phospholipase C was kindly provided by Dr. A. Saltiel (New York, NY, USA). Agarose bound wheat germ agglutinin (WGA-agarose) was obtained from Vector Laboratories (La Jolla, Calif., USA). Tissue culture plasticware was from NUNC (Copenhagen, Denmark). Fetal calf serum, Dulbecco's Modified Eagle's medium (DMEM) and RPMI-1640 were supplied from Gibco (Grand Island, NY, USA). All other chemicals were of analytical grade and obtained from standard suppliers.

\section{Cell culture}

All experiments were performed with cultured NIH $3 \mathrm{~T} 3$ cells transfected with human insulin receptor cDNA (kindly provided by J. Whittaker et al. [32] referred to as NIH 3 T3 HIR 3.5 and IM-9 lymphoblastoid cells [33]. The IM-9 cells were grown in suspension in RPMI-1640 with $10 \%$ fetal calf serum; the $3 \mathrm{~T} 3$ cells were grown in DMEM supplemented with $10 \%$ fetal calf serum. Both cells types were propagated in a humidified atmosphere at $37^{\circ} \mathrm{C}$ with $5 \% \mathrm{CO}_{2}$. The 3T3 cells were subcultured after reaching confluence by $1: 5$ dilution of cell released from plates by trypsin, whereas the IM-9 cells were subcultured by simple 1:5 dilution.

\section{Insulin binding}

Fibroblasts were plated in $10 \mathrm{~cm}$ culture dishes. At confluency, the cells were washed twice with $5 \mathrm{ml}$ of binding buffer $(100 \mathrm{mmol} / 1$ Hepes, $120 \mathrm{mmol} / 1 \mathrm{NaCl}, 5 \mathrm{mmol} / 1 \mathrm{KCl}, 1.2 \mathrm{mmol} / 1 \mathrm{MgSO}_{4}$, $8 \mathrm{mmol} / 1$ glucose and $1 \%$ bovine serum albumin), $\mathrm{pH} 8$, and incubated with A14-labelled $\left.{ }^{125} \mathrm{I}\right]$ insulin and various concentrations of unlabelled insulin. After $3 \mathrm{~h}$ at $15^{\circ} \mathrm{C}$, the cells were washed three times with cold phosphate buffer, $\mathrm{pH} 7.4$, and solubilized with $0.1 \%$ sodium dodecyl sulphate (SDS), and the radioactivity in the samples was counted. Non-specific binding was determined in parallel samples containing $10 \mu \mathrm{g} / \mathrm{ml}$ of unlabelled insulin. Specific insulin binding (total minus non-specific) was expressed as percent bound per milligram protein [34]. The procedure was essentially the same for
IM-9 lymphocytes, except for slight modifications since these cells were in suspension. For IM-9 cells the results were expressed as a percent bound per $1 \times 10^{7}$ cells [33].

\section{Insulin receptor phosphorylation}

The NIH 3T3 HIR 3.5 cells were plated onto $10 \mathrm{~cm}$ dishes and allowed to reach confluence. The cells were placed in serumfree DMEM with $0.1 \%$ bovine serum albumin for $12 \mathrm{~h}$ followed by phosphate-free DMEM containing ${ }^{32} \mathrm{P}$-orthophosphate $(0.1 \mathrm{mCi} / \mathrm{ml})$ for $2 \mathrm{~h}$. The labelled cells were treated with different concentrations of phospholipase $C$ and then stimulated with insulin $(1 \mu \mathrm{g} / \mathrm{ml})$ for $10 \mathrm{~min}$. The reaction was stopped instantaneously by the addition of liquid nitrogen, and the cells allowed to thaw into chilled solubilizing buffer containing $50 \mathrm{mmol} / 1 \mathrm{Hepes}$, $1 \%$ Triton $X-100,5 \mathrm{mmol} / 1$ ethylenediaminetetraacetic acid (EDTA), $100 \mathrm{mmol} / \mathrm{l}$ sodium fluoride, $10 \mathrm{mmol} / \mathrm{l}$ sodium pyrophosphate, $2 \mathrm{mmol} / 1$ sodium orthovanadate, aprotinin $(1,000 \mathrm{kal}-$ likrein units $/ \mathrm{ml}$ ), and $2 \mathrm{mmol} / \mathrm{l}$ phenylmethylsulphonyl fluoride (PMSF), $\mathrm{pH} 7.4$. The cell lysate was centrifuged at $200,000 \mathrm{~g}$ for $60 \mathrm{~min}$, and the supernatant was incubated with rabbit polyclonal anti-phosphotyrosine antibodies at $4^{\circ} \mathrm{C}$ for $10 \mathrm{~h}$. The immune complexes were precipitated by the addition of Protein A (Pansorbin, Calbiochem) as previously described [15] and prepared for SDSpolyacrylamide gel electrophoresis under reducing conditions (100 $\mathrm{mmol} / \mathrm{l}$ dithiothreitol) according to the method of Laemmli [35]. Autoradiography of the dried gels was performed, and the appropriate areas of the radiographs quantitated by scanning densitometry. The relative level of phosphorylation of the insulin receptor $\beta$-subunit and pp 185 were expressed as percent of control stimulation of each by insulin alone. In some experiments varying concentrations of phospholipase $\mathrm{C}$ were added to some plates of cells for $40 \mathrm{~min}$ at $37^{\circ} \mathrm{C}$ prior to insulin stimulation. The procedure was essentially the same for IM-9 lymphocytes, except that the cells were in suspension.

\section{Lectin purification of the insulin receptor}

The insulin receptor was partially purified from IM-9 lymphocytes or NIH 3 T3 cells by wheat germ agglutinin affinity chromatography. Confluent cells were solubilized at $22^{\circ} \mathrm{C}$ with $3 \mathrm{ml}$ of $50 \mathrm{mmol} / \mathrm{l}$ Hepes, $\mathrm{pH} 7.4$, containing $1 \%$ Triton $\mathrm{X}-100,0.1 \mathrm{mg} / \mathrm{ml}$ aprotinin and $2 \mathrm{mmol} / \mathrm{l}$ PMSF. Following centrifugation to remove the insoluble material, the cell extract was applied to a $1 \mathrm{ml}$ WGA-agarose column, and the insulin receptor was eluted with $1-2 \mathrm{ml}$ of $0.3 \mathrm{~mol} / 1$ $\mathrm{N}$-acetylglucosamine in $50 \mathrm{mmol} / 1$ Hepes, pH 7.4, $0.1 \%$ Triton X100 . Insulin binding was performed on the partially purified receptor preparations at $4^{\circ} \mathrm{C}$ for $15 \mathrm{~h}$ using the polyethylene glycol precipitation method as previously described [36].

\section{Insulin receptor autophosphorylation}

Autophosphorylation of the insulin receptor was studied using partially purified receptor preparations adjusted to give similar insulin receptor concentrations. Insulin binding was performed at $4^{\circ} \mathrm{C}$ for $15 \mathrm{~h}$. The sample was then brought to $20^{\circ} \mathrm{C}$, and phosphorylation initiated by adding $\mathrm{MnCl}_{2}$ ( $3 \mathrm{mmol} / \mathrm{l}$ final concentration), $25 \mu \mathrm{mol} / 1$ cold ATP, and $5 \mu \mathrm{Ci}\left[\gamma^{32} \mathrm{P}\right] \mathrm{ATP}$ for $10 \mathrm{~min}$. The reaction was stopped by the addition of Laemmli sample buffer and boiling for $3 \mathrm{~min}$. The proteins were separated on $7.5 \%$ polyacrylamide gel electrophoresis according to Laemmli, and the gel was analysed by autoradiography. ${ }^{32} \mathrm{P}$-incorporation into the $\beta$-subunit of the insulin receptor was quantitated by scanning densitometry of the films. 


\section{Results}

\section{Effect of phospholipase C on insulin receptor and substrate phosphorylation}

NIH 3T3 HIR 3.5 fibroblasts were labelled with ${ }^{32} \mathrm{P}$-orthophosphate then incubated with phospholipase $\mathrm{C}$ from C. perfrigens for $40 \mathrm{~min}$ at $37^{\circ} \mathrm{C}$ prior to insulin stimulation. Phosphotyrosine-containing proteins were isolated from solubilized cells using anti-phosphotyrosine antibodies and analysed by SDS electrophoresis. Insulin $(1 \mu \mathrm{g} / \mathrm{ml})$ stimulated the phosphorylation of the 95 kilodalton $\beta$-subunit of its own receptor (Fig. 1, lanes 1 and 2). The phosphorylation of the insulin receptor was reduced in a dosedependent manner when the cells were treated with phospholipase $\mathrm{C}$ prior to insulin stimulation (Fig.1, lanes 3-6). Based on an average of four experiments there was a $30 \%$ reduction in $\beta$-subunit after treatment with phospholipase Cat a concentration of $0.6 \mathrm{U} / \mathrm{ml}$ and a $50 \%$ reduction at a concentration of $3.4 \mathrm{U} / \mathrm{ml}$ (Fig. 2). The basal level of receptor phosphorylation, as detected by the antireceptor antibodies, was not affected by the treatment with phospholipase $\mathrm{C}$ (data not shown).

Insulin-stimulated phosphorylation of the presumed endogenous substrate for the insulin receptor kinase pp 185 was also reduced by phospholipase $\mathrm{C}$ treatment (faint band in Fig. 1). This phosphorylation was more sensitive to phospholipase $C$ treatment with a $60-70 \%$ reduction of pp 185 phosphorylation at a phospholipase C concentration of $0.6 \mathrm{U} / \mathrm{ml}$ (Fig. 2). Some variability was observed in the control level of insulin stimulation of pp 185 , probably reflecting the sensitivity of $\mathrm{pp} 185$ to phosphotyrosine phosphatases and rapid dephosphorylation or changes in expression in the cell cycle. Treatment of cells with the phosphatidylinositol-specific phospholipase $\mathrm{C}$ did not affect the phosphorylation state of insulin receptor or pp 185 (data not shown).

The time-course of the phospholipase $\mathrm{C}$ effect on receptor autophosphorylation is shown in Figure 3 using $2.3 \mathrm{U} / \mathrm{ml}$ of enzyme. The decrease in insulin-stimulated

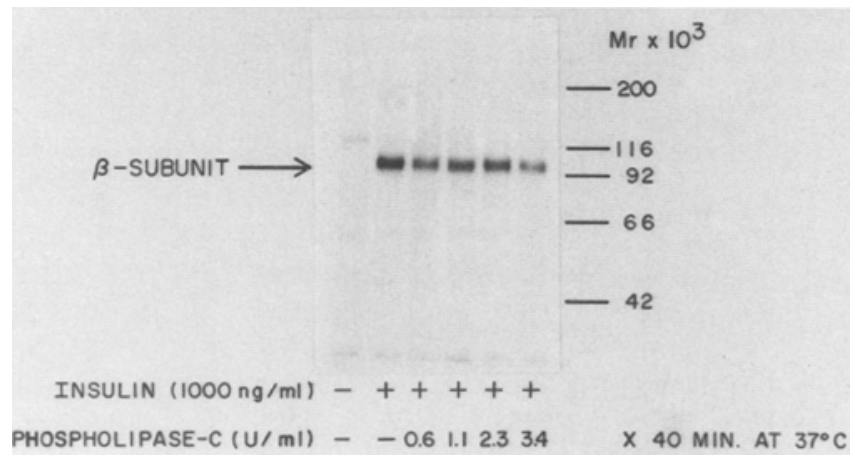

Fig. 1. Effect of phospholipase $\mathrm{C}$ treatment on insulin-stimulated receptor phosphorylation in NIH 3T3 HIR 3.5 fibroblasts. Confluent cells were labelled with [ $\left.{ }^{32} \mathrm{P}\right]$ orthophosphate as described in Materials and methods, then exposed to phospholipase C for $40 \mathrm{~min}$ and finally stimulated with insulin for $10 \mathrm{~min}$. The labelled cells were solubilized, and insulin receptor was immunoprecipitated by antiphosphotyrosine antibodies. The immunoprecipitates were analysed by SDS-PAGE and autoradiography pp 185 was better visualized in longer exposures

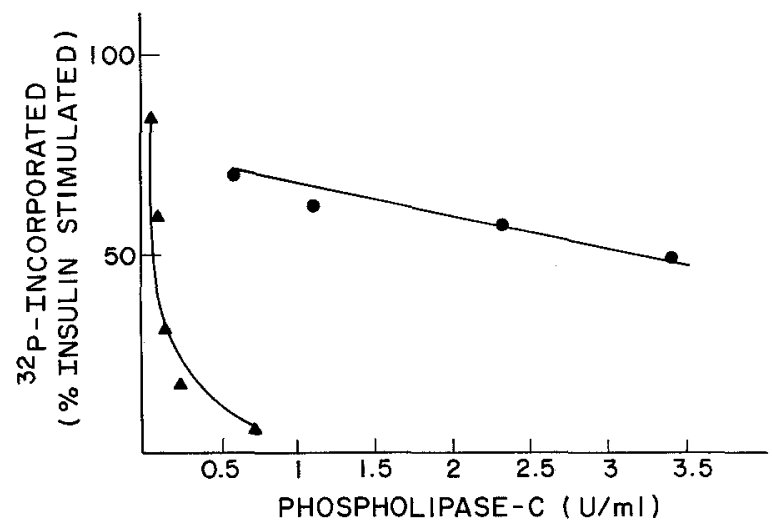

Fig. 2. Effect of phospholipase C on insulin receptor $(\bullet)$ and $p p 185$ $(\triangle)$ phosphorylation. Cells were labelled and phosphoproteins isolated as described in Figure 1. The autoradiograms were then quantitated by scanning densitometry. The amount of phosphate incorporated into the 95 kilodalton ( $\mathrm{kDa}$ ) and $185 \mathrm{kDa}$ bands, expressed as the percent of the insulin-stimulated receptor phosphorylation, is plotted as a function of increasing concentration of phospholipase $C$.
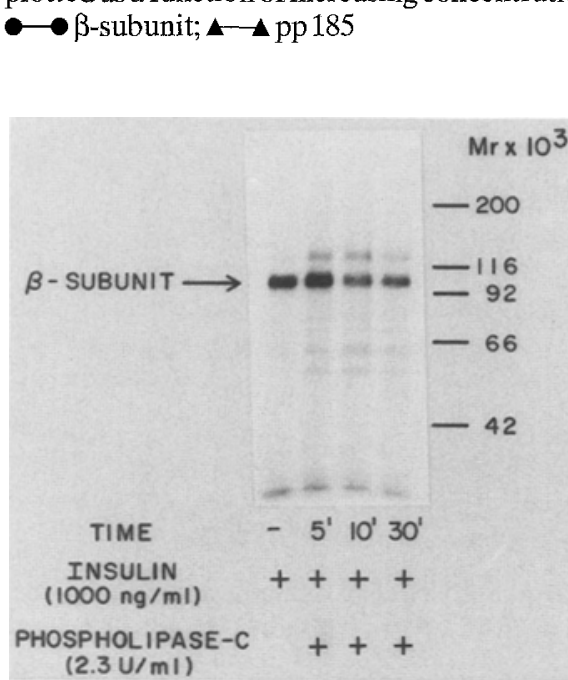

Fig.3. Time-course of phospholipase $C$ treated cells on insulinstimulated phosphorylation of insulin receptor in NIH 3T3 HIR 3.5 fibroblasts. Cells were labelled for $2 \mathrm{~h}$ with $\left[{ }^{32} \mathrm{P}\right]$ orthophos phate, then treated with phospholipase $\mathrm{C}(2.3 \mathrm{U} / \mathrm{ml})$ for $40 \mathrm{~min}$ and stimulated with insulin $(1 \mu \mathrm{g} / \mathrm{ml})$ for $10 \mathrm{~min}$. The reaction was stopped by aspirating the medium and freezing the cells with liquid nitrogen. The frozen cells were allowed to thaw into $1 \mathrm{ml}$ of solubilization buffer containing $1 \%$ Triton X-100 and phosphatase inhibitors as described in Materials and methods. The crude extract was immunoprecipitated with anti-phosphotyrosine antibodies, reduced with DTT, and separated by SDS-PAGE. An autoradiogram was prepared with an intensifying screen of the fixed and dried gel and is shown

phosphorylation was seen within 10 min of incubation and did not progress with further incubation to $30 \mathrm{~min}$. No new phosphoproteins or degradation fragments of the $\beta$-subunit appeared following phospholipase $\mathrm{C}$ treatment.

\section{Effect of phospholipase $C$ on insulin binding and IM-9 lymphocytes}

Insulin binding was assessed at $15^{\circ} \mathrm{C}$ for $3 \mathrm{~h}$ under steadystate conditions. In control NIH 3T3 HIR 3.5 fibroblasts, specific insulin binding was $46.8 \% / \mathrm{mg}$ protein with halfmaximal inhibition of binding being observed at an unla- 


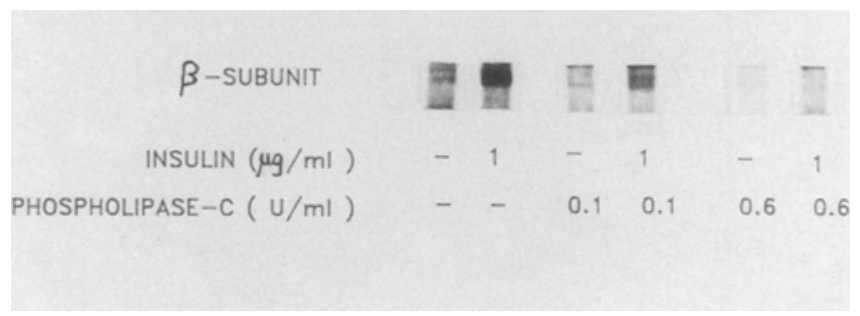

Fig.4. Effect of phospholipase $C$ treatment on insulin-stimulated phosphorylation of insulin receptor in IM-9 lymphocytes. $1 \times 10^{8}$ cells were labelled with $\left.{ }^{32} \mathrm{P}\right]$ orthophosphate in phosphate-free medium, then exposed to the phospholipase $\mathrm{C}$ for $40 \mathrm{~min}$ at $37^{\circ} \mathrm{C}$, and finally stimulated with insulin $\left(10^{7} \mathrm{~mol} / \mathrm{l}\right)$ for $10 \mathrm{~min}$. The cells were centrifuged and the medium aspirated. The cells were immediately solubilized by vortexing in $1 \mathrm{ml}$ of ice-cold solubilizing buffer containing $1 \%$ Triton X-100 and phosphatase inhibitors. The crude extracts were immunoprecipitated by anti-phosphotyrosine antibodies and separated by SDS-PAGE. An autoradiogram is shown

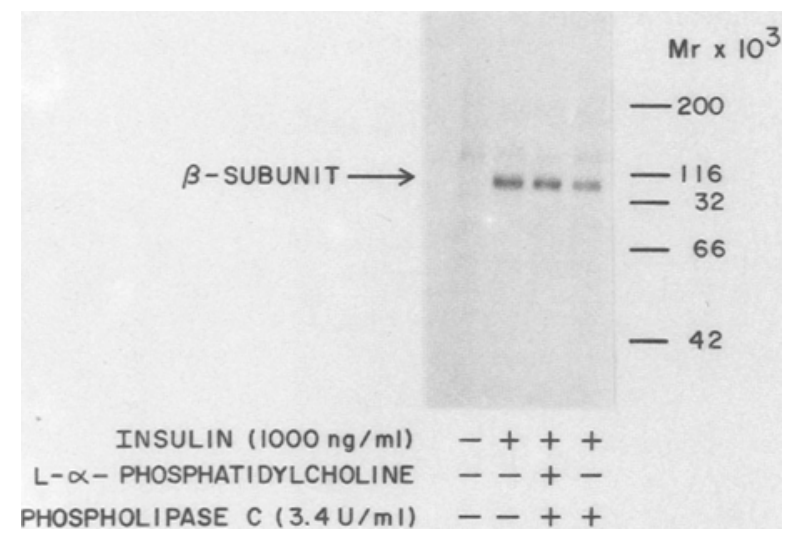

Fig. 5. Effect of L- $\alpha$-phosphatidylcholine on phospholipase C activity. After labelling with $\left[{ }^{32} \mathrm{P}\right]$ orthophosphate, the cells were exposed to phospholipase C either in the presence or in the absence of L- $\alpha$ phosphatidylcholine for $40 \mathrm{~min}$ at $37^{\circ} \mathrm{C}$. After insulin stimulation the crude extract was immunoprecipitated with anti-phosphotyrosine antibodies. The results of the autoradiography are shown

belled insulin concentration of $12 \mathrm{ng} / \mathrm{ml}(\sim 2 \mathrm{nmol} / \mathrm{l})$. Treatment of cells with several concentrations of phospholipase $C$ from 0.6 to $3.4 \mathrm{U} / \mathrm{ml}$ did not affect either total insulin binding or the affinity of the insulin receptor based on complete competition curves and Scatchard analysis (data not shown). Treatment of IM-9 lymphocytes with phospholipase $\mathrm{C}$ also had little or no effect on insulin binding (data not shown). The effect of phospholipase on insulin receptor autophosphorylation, however, was more sensitive in IM-9 cells than with the NIH 3T3 HIR 3.5 cells (Fig.4). Insulin-stimulated $(1 \mu \mathrm{g} / \mathrm{ml})$ phosphorylation was decreased by approximately $80 \%$ with $0.6 \mathrm{U} / \mathrm{ml}$ phospholipase C.

\section{The effects of phospholipase $C$ depend on its action on membrane lipids}

The effect of phospholipase $\mathrm{C}$ is due to its lipolytic action rather than any protease effect. Thus, the inhibitory effect of phospholipase $\mathrm{C}$ on receptor autophosphorylation could be abolished by co-incubation of the phospholipase $C$ with L- $\alpha$-phosphatidylcholine (Fig. 5). In contrast, protease inhibitors, such as aprotinin and PMSF, did not abolish the phospholipase $\mathrm{C}$ effect (data not shown). The effect of phospholipase $\mathrm{C}$ on receptor phosphorylation was also specific. When total extracts from ${ }^{32} \mathrm{P}$-labelled cells were analysed there was no major difference in overall phosphoprotein profile between untreated and treated cells (Fig. 6A), despite the 30-40\% reduction of phosphorylation of immunoprecipitated insulin receptor by antiphosphotyrosine antibodies (Fig. 6B).

To further validate that the effect of phospholipase $\mathrm{C}$ was via its effect on membrane phospholipids, insulin receptors from phospholipase $\mathrm{C}$ treated cells were partially purified on WGA-agarose columns and assayed for insulin binding and for insulin-stimulated receptor autophosphorylation in vitro. In this case, no differences were observed between receptors from treated and untreated cells. Moreover, if phospholipase $\mathrm{C}$ was added to the cells

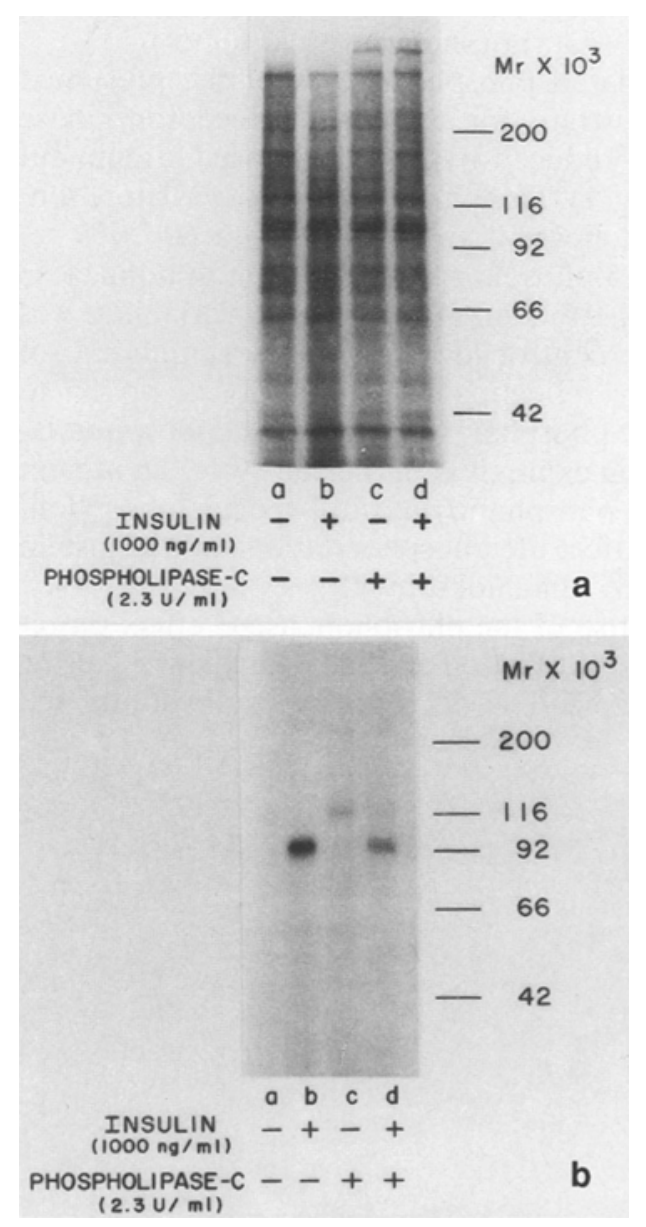

Fig.6. Effect of phospholipase $C$ on insulin-stimulated autophosphorylation of the $\beta$-subunit of the insulin receptor in intact NIH 3T3 HIR 3.5 fibroblasts. Panel a shows the phosphoprotein profile obtained from TCA (10\%) precipitation of $30 \mu \mathrm{l}$ of crude extract; Panel $\mathbf{b}$ is an immunoprecipitation of the same extract with anti-phosphotyrosine antibodies. Both preparations were resuspended in Laemmli buffer with $100 \mathrm{mmol} / \mathrm{l}$ DTT, boiled for $3 \mathrm{~min}$, and the proteins were separated on SDS-PAGE, and identified by autoradiography 
after insulin stimulation, no effect on levels of receptor autophosphorylation was observed (data not shown).

\section{Discussion}

In the present study, we have examined the effect of alterations of plasma membrane lipids on insulin action by digestion of cells with two different phospholipase C preparations. One phospholipase $\mathrm{C}$ is from C.perfringens and has a broad specificity, but acts primarily as a phosphatidylcholine phosphohydrolase. In general, this phospholipase $\mathrm{C}$ alters the polar head groups of membrane lipids $[29,37]$. The other is a phosphatidylinositol-specific phospholipase C from Staphylococcus aureus which catalyzes exclusively the hydrolysis of glycosyl-phosphatidylinositol anchor [31]. Treatment of intact cells with C.perfringens phospholipase $\mathrm{C}$, but not with the phosphatidylinositol-specific phospholipase $C$, reduced insulin-stimulated receptor autophosphorylation without affecting insulin binding. This inhibitory effect was observed within $10 \mathrm{~min}$ of treatment with phospholipase $\mathrm{C}$, but was not observed in cells which had been first stimulated with insulin. Thus, the phospholipase $\mathrm{C}$ treatment disrupts the transmembrane signalling from the $\alpha$ - and $\beta$-subunit of insulin receptor but does not appear to reduce kinase activity that is established.

Phospholipase C readily hydrolyzes $40-60 \%$ of the phospholipids present in a variety of different biological membranes $[29,37]$. This treatment can change the molecular environment around the insulin receptor which ultimately affects insulin receptor signalling [38]. Previous studies of insulin receptors reconstituted in vesicles of different lipid composition suggest that the membrane lipid environment, especially the degree of unsaturation of the phospholipid fatty acylchains, can influence the binding properties of insulin receptor [39]. The decreased levels in insulin-stimulated autophosphorylation observed in these experiments are due to altered signal propagation rather than to a direct action of phospholipase Con insulin receptor binding since, under our conditions, binding does not appear to be affected. Furthermore, this effect was due to the lipid hydrolyzing action of these enzymes and was inhibited by addition of phosphatidylcholine. Protease inhibitors did not eliminate the phospholipase $\mathrm{C}$ effect, ruling out a role for possible contaminating proteases in these observations. More importantly, when the insulin receptor was partially purified on WGA and the autophosphorylation assay was carried out in an in vitro system, there was no difference between treated and untreated cells. Thus, when the insulin receptor was reconstituted in an environment where most membrane lipids were replaced by detergent (Triton X-100), the effect of phospholipase C treatment was nolonger present [40].

From these results, we conclude that the alterations in the lipid environment caused by phospholipase $\mathrm{C}$ are responsible for the effect on insulin receptor autophosphorylation. Exactly how changing the lipid environment might alter receptor kinase activation is uncertain. It is possible that the lipid environment plays an important permissive role in some change in receptor conformation or aggregation induced by insulin and required for normal signal transduction. Phospholipase treatment may also change the surface charge properties of the membrane and produce some electrostatically unfavourable environment for transmembrane signalling [41]. Indeed, it is possible that the phospholipase effect is not specific to the insulin receptor and also affects membrane receptors for other ligands such as the EGF or IGF-I receptors. Recent data in our laboratory (Huertas, P., Kahn, C. R., unpublished observation) in which receptors have been incorporated into a variety of different lipids suggest that the nature of the polar head group, as well as fatty acid chain length and unsaturation can have major effects on the ability of insulin to activate the receptor kinase.

An alterative explanation could be that exogenously added phospholipase $C$ leads to an increased level of diacylglycerol in cells which in turn could activate protein kinase $\mathrm{C}[42,43]$. Protein kinase Can phosphorylate the insulin receptor on serine and threonine residues resulting in a decrease in tyrosine kinase activity $[44,45]$. In our experiments, however, even after $40 \mathrm{~min}$ of treatment with phospholipase $C$, there was no change in the basal level of receptor phosphorylation as detected by immunoprecipitation with both anti-phosphotyrosine antibodies and anti-insulin receptor antibody. Furthermore, there is evidence that in other cell types incubation with phospholipase $C$ causes a loss, rather than an increase, in protein kinase $\mathrm{C}$ activity in the particulate fraction [46].

Insulin-stimulated phosphorylation of pp 185, the putam tive substrate for insulin receptor kinase [47], was more markedly inhibited by phospholipase $\mathrm{C}$ treatment than that of receptor itself. Based on in vitro mutagenesis, the binding site for this substrate has been localized in the juxtamembrane region of the $\beta$-subunit of insulin receptor [48]. Thus, alterations in the lipid environment could either directly affect the interaction between insulin receptor and pp 185 or inhibit same change in conformation necessary to expose the substrate binding site. This point deserves further study.

Cuatrecasas showed that digestion of adipocytes and liver cell membranes with phospholipase $C$ led to a threesix-fold increase in specific insulin binding with no change in glucagon binding [25]. In adipocytes this was accompanied by a loss in insulin-stimulated glucose oxidation, even at low concentrations of phospholipase at which the insulin binding was unchanged. In the present study, no increase in insulin binding was observed. This may be due to different phospholipase $\mathrm{C}$ preparations or to differences in membrane lipids in the different cells used. However, we did find a dramatic effect of phospholipase $\mathrm{C}$ on insulin receptor phosphorylation despite the presence of normal insulin binding. Thus, in both systems phospholipase $C$ treatment resulted in a post-binding form of insulin resistance.

An alternative approach to study the effects of lipid modification on receptor function is to attempt to alter cell membrane lipid composition by culture of cells in media supplemented with different lipids. This technique has been used to show effects of lipids on both insulin binding and insulin action in 3T3-L1 cells [19], hepatoma cells [10] and a variety of other cell types [8]. Recently 
Bruneau and colleagues [10] have studied insulin action in rat hepatoma cells whose membrane lipid composition was altered by supplementation of the culture medium with linoleic acid or 25-hydroxycholesterol. In this model, they found that the induced alteration in the lipid composition resulted in alterations on both binding and biological actions of insulin, creating an insulin resistant state, although the exact site of the resistance to insulin action remained uncertain.

In summary, our data suggest that phospholipase $\mathrm{C}$ treatment of cells affects insulin action by altering transmembrane signalling by the insulin receptor. Thus, membrane lipid composition may have profound effects on this earliest event in insulin action. Similarly, alterations of membrane lipid composition might be involved in insulin resistance states such as obesity or non-insulin-dependent diabetes mellitus [49-51]. Clearly, more studies of regulation of insulin receptor activity by lipids are needed to define the critical role these membrane components may play in insulin signal transduction, and how this may contribute to insulin resistant states.

Acknowledgements. This work was supported in part by NIH grant DK 31036 and the Joslin Diabetes Endocrinology Research Center grant (DK 36836). The authors also wish to thank Ms. T.-L.Bellman for secretarial assistance.

\section{References}

1. Singer SJ, Nicolson GL (1972) The fluid mosaic model of structure of cell membranes. Science 175: 720-731

2. Mountford CE, Wright LC (1988) Organization of lipids in the plasma membranes of malignant and stimulated cells: a new model. TIBS 13: 172-177

3. Loh HH, Law PY (1980) The role of membrane lipids in receptor mechanisms. Ann Rev Pharmacol Toxicol 20: 201-234

4. Spector AA, Yorek MA (1985) Membrane lipid composition and cellular function. J Lipid Res 26: 1015-1035

5. Stubbs CD, Smith AD (1984) The modification of mammalian membrane polyunsaturated fatty acid composition in relation to membrane fluidity and function. Biochim Biophys Acta 779: 89137

6. Gould RJ, Ginsberg BH (1985) Membrane fluidity in biology. In: Alioa J (ed) Membrane fluidity in biology, Vol3. Academic Press, New York, pp257-280

7. Sanderman H (1978) Regulation of membrane enzymes by lipids. Biochem Biophys Acta 515:209-237

8. Ginsberg BH, Brown TJ, Simon I, Spector AA (1981) Effect of the membrane lipid environment on the properties of insulin receptor. Diabetes 30: 773-780

9. Grunfeld C, Baird KL, Kahn CR (1981) Maintenance of 3T3-L1 cells in culture media containing saturated fatty acids decreases insulin binding and insulin action. Biochem Biophys Res Commun 103: 219-226

10. Bruneau C, Hubert P, Waksman A, Beck JP, Steedel-Fleig C (1987) Modifications of cellular lipids induce insulin resistance in cultured hepatoma cells. Biochem Biophys Acta 928: 297-304

11. Kasuga M, Hedo JA, Yamada KM, Kahn CR (1982) The structure of the insulin receptor and its subunits: evidence for multiple non-reduced forms and a $210 \mathrm{~K}$ possible proreceptor. J Biol Chem 257: 10392-10399

12. Hedo JA, Kahn CR, Hayashi M, Yamada KM, Kasuga M (1983) Biosynthesis and glycosylation of the insulin receptor: evidence for a single polypeptide precursor of the two major subunits. J Biol Chem 258: 10020-10026
13. Ebina Y, Ellis L, Jarnagin K et al. (1985) The human insulin receptor CDNA: the structural basis for hormone-activated transmembrane signalling. Cell 40: 747-758

14. Kahn CR, White MF (1988) The insulin receptor and the molecular mechanism of insulin action. J Clin Invest 82: 1151-1156

15. White MF, Shoelson SE, Keutmann H, Kahn CR (1988) A cascade of tyrosine autophosphorylation in the $\beta$-subunit activates the phosphotransferase of the insulin receptor. J Biol Chem 263: $2969-2980$

16. Yu KT, Czech MP (1984) Tyrosine phosphorylation of the insulin receptor $\beta$-subunit activates the receptor-associated tyrosine kinase activity. J Biol Chem 259: 5277-5286

17. Herrera R, Rosen OM (1986) Autophosphorylation of the insulin receptor in vitro. J Biol Chem 261: 11980-11985

18. Ellis LD, Morgan O, Clauser E et al. (1986) Mechanisms of receptor mediated transmembrane communication. In: Mechanisms of receptor mediated transmembrane communication. Cold Spring Harbor Symposium 51: 773-784

19. Ebina YE, Araki E, Taira M et al. (1987) Replacement of lysine residue 1030 in the putative ATP-binding region of the insulin receptor abolishes insulin- and antibody-stimulated glucose uptake and receptor kinase activity. Proc Natl Acad Sci USA 84: 704-708

20. Morgan DO, Roth RA (1987) Acute insulin action requires insulin receptor kinase activity: introduction of an inhibitory monoclonal antibody into mammalian cells blocks the rapid effects of insulin. Proc Natl Acad Sci USA 84: 41-45

21. Amatruda JM, Finch D (1979) Modulation of hexose uptake and insulin action by cell membrane fluidity. The effects of temperature on membrane fluidity, insulin action and insulin binding. $J$ Biol Chem 254: 2619-2625

22. McCaleb ML, Donner DB (1981) Affinity of the hepatic insulin receptor is influenced by membrane phospholipids. J Biol Chem 256: 11051-11057

23. Hedo JA, Collier E, Watkinson A (1987) Myristyl and palmityl acylation of the insulin receptor. J Biol Chem 262: 954-957

24. Magee AI, Schlessinger MJ (1982) Fatty acid acylation of eucaryotic cell membrane proteins. Biochim Biophys Acta 694: 279 284

25. Cuatrecasas $P$ (1971) Unmasking of insulin receptors in fat cells and fat cell membranes: perturbation of membrane lipids. J Biol Chem 246: 6532-6542

26. Saltiel AR, Cuatrecasas P (1986) Insulin stimulates the generation from hepatic plasma membranes of modulators derived from an inositol glycolipid. Proc Natl Acad Sci USA 83: 57335737

27. Romero G, Luttireli L, Rogol A, Zeller K, Hewlett E, Larner J (1988) Phosphatidylinositol-glycan anchors of membrane proteins: potential precursors of insulin mediators. Science 240: 509 512

28. Gaulton GN, Kelley KL, Pawlowski J, Mato JM, Jarett L (1988) Regulation and function of an insulin-sensitive glycosyl-phosphatidylinositol during lymphocytes activation. Cell 53: 963-970

29. Takahashi T, Sugahara T, Ohsaka A (1974) Purification of Clostridium perfringens phospholipase $\mathrm{C}$ (alpha-toxin) by affinity chromatography on agarose-linked egg-yolk lipoprotein. Biochim Biophys Acta 351: 155-171

30. Sundler R, Alberts AW, Vagelos PR (1978) Phospholipases as probes for membrane sideness. Selective analysis of the outer monolayer of asymmetric bilayer vesicles. J Biol Chem 253: 5299-5304

31. Low MG, Saltiel AR (1988) Structural and functional roles of glycosyl phosphatidylinositol in membranes. Science 239: 268275

32. Whittaker J, Okamoto AK, Thys R, Bell GL, Steiner DF, Hofmann CA (1984) High-level expression of human insulin receptor cDNA in mouse NIH 3T3 cells. Proc Natl Acad Sci USA 84: 5237-5241

33. Gavin JR III, Roth J, Jen P, Freychet P (1972) Insulin receptors in human circulating cells and fibroblasts. Proc Natl Acad Sci USA 69: 747-751 
34. Podskalny JM, Kahn CR (1982) Cell culture studies on patients with extreme insulin resistance. I. Receptor defects in cultured fibroblasts. II. Abnormal biological responses in cultured fibroblasts. J Clin Endocrinol Metab 54: 261-275

35. Laemmli UK (1970) Cleavage of structural proteins during the assembly of the head of bacteriophage T4. Nature 277: 680-682

36. Grigorescu F, Flier JS, Kahn CR (1986) Characterization of binding and phosphorylation defects of insulin receptors in the Type A syndrome of insulin resistance. Diabetes 35: 127-138

37. Lenard J, Singer SJ (1968) Structure of membranes: reaction of red blood cell membranes with phospholipase C. Science 159: 738-739

38. Carruthers A, Melchior DL (1986) How bilayer lipids affect membrane protein activity. TIBS 11:331-335

39. Gould RJ, Ginsberg BH, Spector AA (1982) Lipid effects on the binding properties of a reconstituted insulin receptor. $J$ Biol Chem 257: 477-484

40. Avruch J, Nemenoff RA, Blackshear PJ, Pierce MW, Osathanondh R (1982) Insulin-stimulated tyrosine phosphorylation of the insulin receptor in detergent extracts of human placental membranes. J Biol Chem 257: 15162-15166

41. Corda D, Pasternak C, Shinitsky M (1982) Increase in lipid microviscosity of unilamaellar vesicles upon the creation of transmembrane potential. J Membr Biol 65: 235-242

42. Goldman J, Achenkunju G (1988) Role of phospholipase Cproducts in the stimulation of adipocyte hexose uptake by insulin. Diabetes 37 [Suppl 1]: 36 A (Abstract)

43. Exton JH (1990) Signaling through phosphatidylcholine breakdown. J Biol Chem 265: 1-4

44. Koshio O, Akanuma Y, Kasuga M (1989) Identification of a phosphorylation site of the rat insulin receptor catalyzed by protein kinase $C$ in an intact cell. FEBS Lett 254: 22-24
45. Takayama S, White MF, Lauris V, Kahn CR (1984) Phorbol esters modulate insulin receptor phosphorylation and insulin action in cultured hepatoma cells. Proc Natl Acad Sci USA 81: 7797-7801

46. Jones MJ, Murray AW (1986) Effect of membrane perturbation on protein kinase $\mathrm{C}$ activation: treatment with exogenous phospholipase $\mathrm{C}$ decreases translocation of enzyme to cellular membranes. Biochem Biophys Res Commun 136: 1083-1089

47. White MF, Maron R, Kahn CR (1985) Insulin rapidly stimulates tyrosine phosphorylation of an $M_{r} 185,000$ protein in intact cells. Nature 318: 183-186

48. White MF, Livingston JN, Backer JM et al. (1988) Mutation of the insulin receptor at tyrosine 960 inhibits signal transmission but does not affect its tyrosine kinase activity. Cell 54: 641-649

49. McMillan DE (1983) Insulin, diabetes, and the cell membrane: an hypothesis. Diabetologia 24: 308-310

50. Bryszewska M, Watala C, Torzecka W (1986) Changes of fluidity and composition of erythrocyte membranes and in composition of plasma lipids in Type I diabetes. Br $\mathbf{J}$ Haemotol 62:111-116

51. Winocour PD, Bryszewska M, Watala C et al. (1990) Reduced membrane fluidity in platelets from diabetic patients. Diabetes 39: 241-244

Received: 28 May 1991

and in revised form: 15 October 1991

Dr. C.R.Kahn

Joslin Diabetes Center

One Joslin Place

Boston, MA 02215

USA 